\title{
Age-Related Body Composition Differences in Female Police Officers
}

\author{
Diferencias de Composición Corporal Relacionadas \\ con la Edad en Oficiales de la Policía Femenina
}

Filip Kukic'; Aleksandra Scekic ${ }^{1}$; Nenad Koropanovski²; Aleksandar Cvorovic ${ }^{1}$; Jay J. Dawes ${ }^{3}$ \& Milivoj Dopsaj ${ }^{4,5}$

KUKIC, F.; SCEKIC, A.; KOROPANOVSKI, N.; CVOROVIC, A.; DAWES, J. J. \& DOPSAJ, M. Age-related body composition differences in female police officers. Int. J. Morphol., 37(1):302-307, 2019.

SUMMARY: Since performance in police occupations may depend on body composition and physical abilities, women are less likely to become police officers. However, information on age-related differences in body composition among female police officers (FPO) barely exists. Thus, this study aimed to investigate the association between age and body composition in FPO. Body composition of 95 FPO was assessed and divided into 4 age groups: $21-25$ (age $=23.58 \pm 0.84$ years, body height $[\mathrm{BH}]=1.61 \pm 0.04 \mathrm{~m}$, body mass $[\mathrm{BM}]=65.55 \pm 12.59 \mathrm{~kg}) ; 26-30($ age $=28.24 \pm 1.20$ years, $\mathrm{BH}=1.61 \pm 0.04 \mathrm{~m}, \mathrm{BM}=72.08 \pm 12.80 \mathrm{~kg}) ; 31-35(\mathrm{age}=32.73 \pm 1.59$ years, $\mathrm{BH}=1.62 \pm 0.06 \mathrm{~m}, \mathrm{BM}=74.88 \pm 12.22 \mathrm{~kg})$; and $36-40(\mathrm{age}=37.71 \pm 1.40$ years, $\mathrm{BH}=1.61 \pm 0.08 \mathrm{~cm}, \mathrm{BM}=77.38 \pm 11.61 \mathrm{~kg})$. Eight body composition characteristics were measured using bioelectrical impedance (InBody 720): BM, body mass index (BMI), fat mass index (FMI), fat mass (FM), trunk fat mass (TFM), percent body fat mass (PBF), skeletal muscle mass (SMM), and percent skeletal muscle mass (PSMM). A multivariate analysis of variance (MANOVA) with Bonferroni post-hoc test $(p<0.05)$ and Cohen's effect size (ES) were used to determine significant differences in anthropometric variables by age. Statistically significant differences occurred in $\mathrm{BM}(\mathrm{F}=3.412, \mathrm{p}=0.021), \mathrm{BMI}(\mathrm{F}=3.662, \mathrm{p}=0.015), \mathrm{FM}(\mathrm{F}=3.411, \mathrm{p}=0.021)$ and $\mathrm{FMI}(\mathrm{F}=3.479, \mathrm{p}=0.019)$. A large inverse ES occurred in trend of age-related differences in PBF and PSMM. The BM is higher relative to age due to FM, which may cause a decrease in PSMM. The most critical period seems to be between 30-35 years.

KEY WORDS: Body mass; Body fat; Muscle; Body changes.

\section{INTRODUCTION}

The basic elements of law enforcement duties involve high-risk arrests, firefighting interventions, and other activities in order to maintain environment safe and secure (Wells, 2007; Kelly \& Jameson, 2016; Hauschild et al., 2017; Kirlin et al., 2017). Accordingly, physical fitness was always one of the excluding factors for these occupations, and therefore women were less likely to meet the physical fitness standards than men (Anderson et al., 2001). However, in the last few decades, women have become employed in police workforce more often than before. For these reasons, recruitment standards for female police officers (FPO) were set and re-evaluated in order to avoid gender discrimination but also to facilitate the recruitment of women who will be able to perform the job safely, both for them and for the public (Wells; Hauschild et al.).
The performance of various police occupations is shown to be associated with physical fitness, which is consisted of body composition and physical abilities (Anderson \& Plecas, 2000; Dawes et al., 2014; Kelly \& Jameson). Body composition, determined by lifestyle (Kukic \& Dopsaj, 2017) and genetics (Wells), has often been used as an indicator of person's general health status and as a predictor of police officers' physical abilities (Mitrovic et al., 2015; Pihlainen et al., 2018). However, the variations in human body composition are evident which often can be associated with a movement potential such as strength and aerobic endurance (Mitrovic et al.) which may manifest in performing police duties (Dawes et al., 2014; Pihlainen et $a l$.). For instance, increased levels of body mass and body fat can create greater physiological burden when performing

\footnotetext{
${ }^{1}$ Police Sports Education Center, Abu Dhabi, United Arab Emirates.

${ }^{2}$ University of Criminal Investigatios and Police Studies, Belgrade, Serbia.

${ }^{3}$ Health Sciences Department, University of Colorado, Colorado Springs, U.S.A.

${ }^{4}$ Department for Analysis and Diagnosis in Sport, Faculty of Sport and Physical Education, University of Belgrade, Serbia

${ }^{5}$ SUSU, South Ural State University, Chelyabinsk, Russia.
} 
occupational tasks, negatively affect stamina, and reduce aerobic performance (Dawes et al., 2014; Mitrovic et al.). Similarly, the fact that police work can be psychologically very stressful can lead to significant physiological oxidative stress (Charles et al., 2008), while body fat mass over criterion levels increases the risk of cardio-vascular diseases, high blood pressure, diabetes and mortality (Stevens et al., 1998). Additionally, body composition indicators such as body mass, body mass index and fat mass correlate with lower occupational physical ability, which is associated with increased risk of injuries (Dawes et al., 2014; Orr et al., 2017). Once police officers enroll for policing duties, their body mass, body mass index, fat mass and waist circumference typically get higher during the time spent in the service, likely due to a decrease in physical activity (Sörensen et al., 2000; Boyce et al., 2008). Thus, risk of injuries, reduced occupational ability and health disparities increase over time.

Body composition in police occupations has been widely investigated but mostly in the male population. Some longitudinal (Kirlin et al.; Boyce et al.) and cross-sectional studies (Birzer \& Craig, 1996; Dawes et al., 2017; Dimitrijevic et al., 2013) reported results on men and women. Moreover, body composition is often used as an indicator of a person's general health status and as a predictor of functional abilities (Dimitrijevic et al.; Kukic et al., 2018; Pihlainen et al.). However, the dimorphism between male and female human body composition is evident from an early age (Wells), which particularly manifests in traditionally men's professions (Boyce et al.; Dawes et al., 2017). In that regard, there is a gap in scientific literature regarding the differences in body composition as a function of age in FPO. Thus, the aim of this study was to investigate the association between age and body composition in FPO. The main hypothesis was that body composition would be influenced by age. More specifically, body mass and fat components would be higher, while skeletal muscle mass would remain relatively unchanged relative to age.

\section{MATERIAL AND METHOD}

This investigation could be classified as an observational comparative study, whereby data were collected as a regular part of the work setting, according to the previously described protocol (Dopsaj et al., 2017; Kukic et al.).

Subjects. Anthropometric data for Ninety-five $(n=95)$ FPO was collected and divided into four groups according to age: $21-25$ (age $=23.58 \pm 0.84$ years, body height $[\mathrm{BH}]=1.61 \pm$ $0.04 \mathrm{~m}$, body mass $[\mathrm{BM}]=65.55 \pm 12.59 \mathrm{~kg}) ; 26-30($ age $=$
$28.24 \pm 1.20$ years, $\mathrm{BH}=1.61 \pm 0.04 \mathrm{~m}, \mathrm{BM}=72.08 \pm 12.80$ $\mathrm{kg}) ; 31-35(\mathrm{age}=32.73 \pm 1.59$ years, $\mathrm{BH}=1.62 \pm 0.06 \mathrm{~m}$, $\mathrm{BM}=74.88 \pm 12.22 \mathrm{~kg})$; and $36-40(\mathrm{age}=37.71 \pm 1.40$ years, $\mathrm{BH}=1.61 \pm 0.08 \mathrm{~cm}, \mathrm{BM}=77.38 \pm 11.61 \mathrm{~kg}$ ). All participants were informed about the purpose of the assessment and aim of the study and were measured only if they voluntarily agreed to be part of it. The research was conducted in accordance with the conditions of Declaration of Helsinki: Recommendations Guiding Physicians in Biomedical Research Involving Human Subjects (Christie, 2000).

Testing. Body composition was measured using the standardized method of multichannel bioelectrical impedance analysis (BIA). BIA machine InBody 720 (Biospace, Co., Ltd), with tetra-polar 8-point tactile electrode system sends bioelectrical currents of different frequencies, each of which estimates the amount of the corresponding tissue by the electrical resistance that certain tissue provides. Comparing to DXA method, InBody 720 was shown correlate with $\mathrm{r}=0.93$ for women. It has also been reliable with ICC $=0.97$ (Aandstad et al., 2014). All measurements were conducted according to the procedures explained in previous research (Dopsaj et al.; Kukic et al.). In short, measurements were taken between 08:00 and 10:00 in the morning; the participants did not have breakfast and were advised not to eat a big meal for dinner and not to exercise the day prior to the measurement. Body height was measured using Seca 769 digital weight scale with stadiometer to the nearest $0.1 \mathrm{~cm}$. The participants stood on a hard horizontal surface with their feet together, and their heels, gluteal muscles, and thoracic part of the back touching the stadiometer. Head was in position of Frankfurt's plane. Nine variables were used for the statistical analysis in this study: body height $(\mathrm{BH})$, presented in $\mathrm{m}$; body mass $(\mathrm{BM})$, presented in $\mathrm{kg}$; body mass index (BMI), presented in $\mathrm{kg} / \mathrm{m}^{2}$; fat mass (FM), presented in $\mathrm{kg}$; trunk fat mass (TFM), presented in kg; skeletal muscle mass (SMM), presented in kg; percent of body fat mass (PBF), presented in \%; percent of skeletal muscle mass (PSMM), presented in \%; and fat mass index (FMI), calculated as $\mathrm{FM} / \mathrm{BH}^{2}$ presented in $\mathrm{kg} / \mathrm{m}^{2}$.

The descriptive statistic was conducted in Microsoft Excel, while multivariate analysis of variance (MANOVA) with Bonferroni post-hock analysis was conducted using Statistical Package for Social Sciences (IBM, SPSS Statistics 20 ). The significance level was set at $p<0.05$. Effect sizes (ES) were calculated as the differences in mean scores as a proportion of the standard deviation, following the formula: $\mathrm{ES}=(\mathrm{M} 2-\mathrm{M} 1) / \mathrm{SD} 1$, where $\mathrm{M} 1$ and $\mathrm{M} 2$ are the means of the groups being investigated. The magnitude of the effects was defined as follows: small $=0.2$, moderate $=0.6$, large $=$ 1.2 , and very large $=2.0($ Sullivan \& Feinn, 2012). 


\section{RESULTS}

Table I shows means and standard deviations of all measured variables by age groups.

MANOVA results showed that there was no statistically significant differences between the age groups $(\mathrm{F}=1.196, \mathrm{p}=0.205)$. The results of the MANOVA analysis on partial level are presented in Table II. Four out of nine variables, $\mathrm{BM}(\mathrm{F}=3.412, \mathrm{p}=0.021), \mathrm{FMI}(\mathrm{F}=3.479, \mathrm{p}=$ $0.019)$, BMI ( $\mathrm{F}=3.662, \mathrm{p}=0.015)$, and FM (3.411, $\mathrm{p}=$ 0.021 , were significantly different between the age groups.

The Bonferroni analysis revealed that significantly higher values for BM, BMI, FM and FMI occurred between the 21-25 and 36-40 groups (Figs. 1 and 2). The relative difference between the 21-25 and 36-40 groups was 18.42 $\%$ for BM and $19.17 \%$ for BMI (Fig. 1. A,B), while the difference between the same groups was $45.01 \%$ in FM and $46.53 \%$ in FMI (Fig. 2. A,B), with older group being heaving higher values. The relative difference of $14.40 \%$ in
$\mathrm{BM}$ and $13.75 \%$ in BMI between the 21-25 and 31-35 groups was very close of reaching the significance (Fig. 1. A,B). Furthermore, a significant difference in BM was followed by a significant relative difference of $45.01 \%$ in FM and $46.53 \%$ in FMI (Fig. 2. A,B). Although the difference between groups 21-25 and 31-35 was not significant, the ES for BM (0.74), BMI (0.83), FM (0.67) and FMI (0.68) showed a large magnitude in differences. However, comparing FPO aged 21-25 and 36-40 years, the ES almost doubled, whereby $\mathrm{ES}$ for $\mathrm{BW}=0.94$, for $\mathrm{BMI}=1.16$, for FM 1.34, and for FMI = 1.26.

In contrast to BM and indicators of fatness, SMM remained relatively stable across the groups (Table II). Since FM was significantly higher, and SMM remained unchanged, there was an increasing trend in PBF and decreasing in PSMM starting from the youngest FPO group. Additionally, the ES for PBF and PSMM was moderate between 21-25 and 31-35 and large between 21-25 and 36-40, where the difference in ES between the age groups is explained by $89.8 \%$ and $89 \%$ of the shared variance for PBF and SMM, respectively (Fig. 3).

Table I. Descriptive statistics for means and standard deviations.

\begin{tabular}{lcccc}
\hline Group & $21-25$ & $26-30$ & $31-35$ & $36-40$ \\
V ariables & Mean \pm SD & Mean \pm SD & Mean \pm SD & Mean \pm SD \\
\hline Age (years) & $23.58 \pm 0.84$ & $28.24 \pm 1.20$ & $32.73 \pm 1.59$ & $37.71 \pm 1.40$ \\
BH $(\mathrm{m})$ & $1.61 \pm 0.04$ & $1.61 \pm 0.04$ & $1.62 \pm 0.06$ & $1.61 \pm 0.08$ \\
BM $(\mathrm{kg})$ & $65.55 \pm 12.59$ & $72.08 \pm 12.80$ & $74.88 \pm 12.22$ & $77.38 \pm 11.61$ \\
BMI $\left(\mathrm{kg} / \mathrm{m}^{2}\right)$ & $25.13 \pm 4.10$ & $27.71 \pm 5.10$ & $28.54 \pm 4.66$ & $29.90 \pm 4.44$ \\
FMI $\left(\mathrm{kg} / \mathrm{m}^{2}\right)$ & $9.39 \pm 0.73$ & $10.99 \pm 0.93$ & $11.62 \pm 0.68$ & $13.76 \pm 1.13$ \\
FM $(\mathrm{kg})$ & $24.52 \pm 8.62$ & $28.49 \pm 11.94$ & $30.26 \pm 9.40$ & $35.34 \pm 11.98$ \\
TFM $(\mathrm{kg})$ & $12.96 \pm 4.90$ & $15.28 \pm 5.78$ & $16.18 \pm 4.86$ & $17.04 \pm 5.02$ \\
PBF $(\%)$ & $36.86 \pm 8.16$ & $38.64 \pm 11.49$ & $39.94 \pm 9.50$ & $44.90 \pm 10.70$ \\
SMM $(\mathrm{kg})$ & $22.32 \pm 4.55$ & $23.86 \pm 4.70$ & $24.48 \pm 5.09$ & $23.08 \pm 4.09$ \\
PSMM $(\%)$ & $34.27 \pm 4.61$ & $33.54 \pm 6.55$ & $32.89 \pm 5.74$ & $30.23 \pm 6.14$ \\
\hline
\end{tabular}

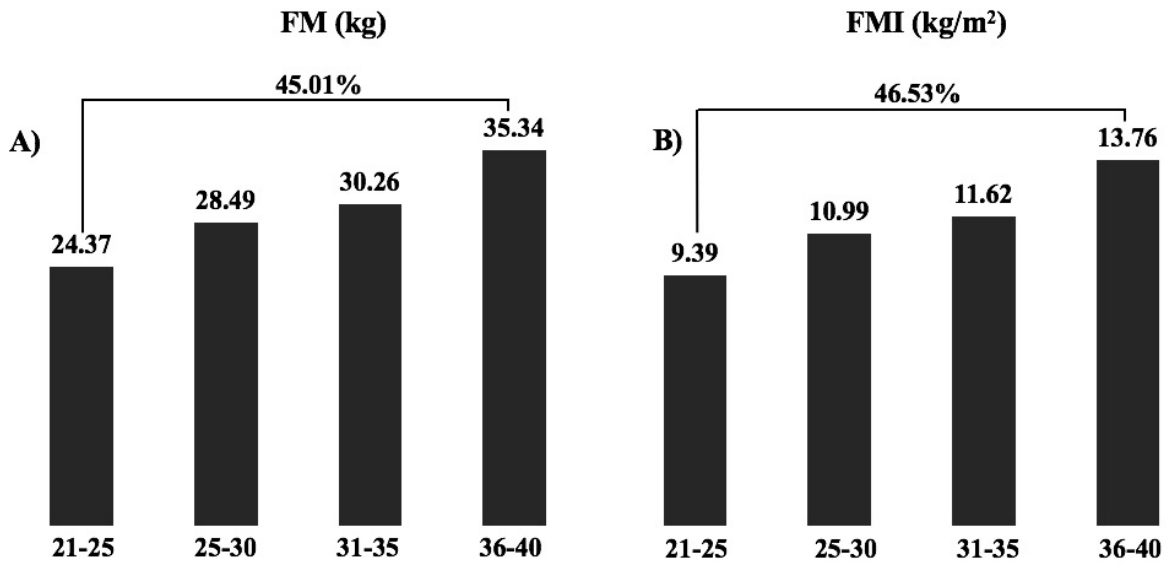

Fig. 1. Differences in BM (A) and BMI (B). 


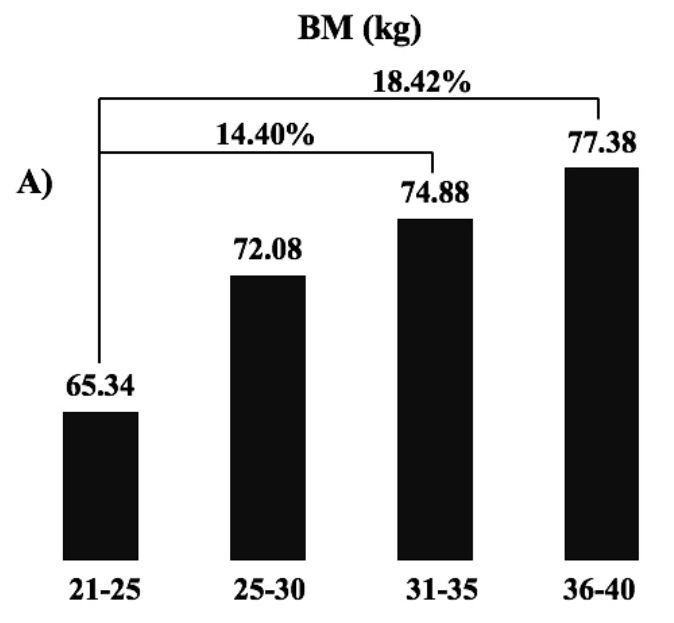

Fig. 2. Differences in FM (A) and FMI (B).

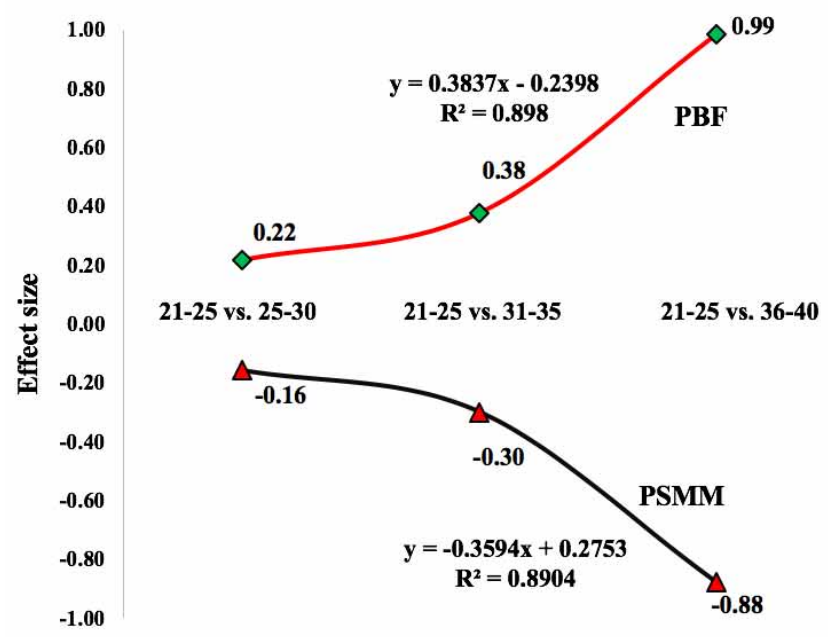

Fig. 3. Effect size for PBF and PSMM.

\section{DISCUSSION}

The purpose of this study was to determine whether significant mean score differences in the body composition status existed among FPO of different ages. The main findings of the study were that BM, BMI, FM, and FMI were different across the age groups, which strongly suggests that the age might have a negative effect on these body composition parameters. The biggest relative differences between the age groups occurred in FMI (46.53\%), while the most significant occurred in BMI. Furthermore, SMM was the same among FPO of different age, while PBF showed
BMI $\left(\mathrm{kg} / \mathrm{m}^{2}\right)$

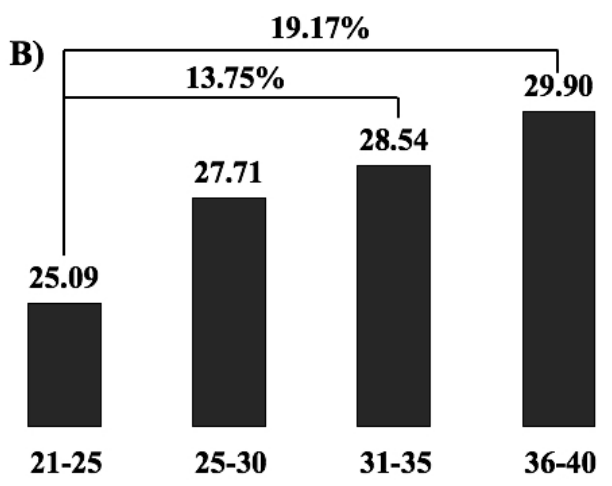

Table II. The MANOVA test of Between-subjects effect on partial level.

\begin{tabular}{lcccc}
\hline V ariable & df & Mean & F & Sig. \\
\hline BH & 3 & .001 & .175 & .913 \\
BM & 3 & 520.175 & 3.412 & $.021^{*}$ \\
FMI & 3 & 59.414 & 3.479 & $.019^{*}$ \\
BMI & 3 & 78.514 & 3.662 & $.015^{*}$ \\
FM & 3 & 373.120 & 3.411 & $.021^{*}$ \\
TFM & 3 & 61.794 & 2.325 & .080 \\
PBF & 3 & 216.498 & 2.154 & .099 \\
SMM & 3 & 21.514 & .968 & .411 \\
PSMM & 3 & 56.412 & 1.661 & .181 \\
$* p<0.05$ & & & & \\
\hline
\end{tabular}

an increasing trend of differences followed by a decreasing trend in PSMM, suggesting that BMI rose significantly due to a higher amounts of BFM that seemingly increases by age. Since there were significant differences in BM, BMI, FM and FMI whereas all groups were with the same BMI, it might be concluded that BMI as an indicator of body composition was not precise and reliable enough. Therefore, this research fills a significant gap in the current literature, as this area has not been previously explored in FPO. Furthermore, the Bonferroni and ES statistics are suggestive 
that the body composition is relatively stable until 31-35 years, while afterwards ES between groups almost doubled for PBF and PSMM (Fig. 2), indicating that rise of PBF might be due to increase in FM of FPO.

The increase in BM, BMI, and FM as a function of the years spent in police service has occurred in extensive follow-up studies (Sörensen et al.; Boyce et al.). The longitudinal study in Finnish police followed 81 police officers for 15 years and found increases in BM by $8.66 \%$ (from $83.1 \mathrm{~kg}$ to $90.3 \mathrm{~kg}$ ) and BMI by $8.33 \%$ (from 25.2 $\mathrm{kg} / \mathrm{m}^{2}$ to $27.3 \mathrm{~kg} / \mathrm{m}^{2}$ ) (Sörensen et al.). More importantly, $64 \%$ of the female participants exceeded the waist circumference of $94 \mathrm{~cm}, 27 \%$ of the officers studied had developed a cardiovascular disease, and $21 \%$ were on medication for high blood pressure, high cholesterol, coronary heart disease or diabetes. Furthermore, a 12.5-year follow-up study on 30 female police officers from North Carolina found that obesity prevalence in FPO increased by $13-15 \%$, whereby FPO gained an average of $11.4 \mathrm{~kg}$ of FM during the follow-up period (Boyce et al.). In both aforementioned studies, insufficient amounts of physical activity and the consequent reduction in the calories burnt during the day were reported as the main reasons for the negative trends in BM, FM, and BMI. Similar increasing trend in BM, FM and BMI was also noticed in the present study, which indicates that FPO might be insufficiently physically active in both, leisure or duty time. In that regards, factorial analysis study conducted on police officers extracted three independent factors of body composition: exerciserelated, sedentary-related and lifestyle-related (Kukic \& Dopsaj), further suggesting that differences in BM, FM, and FMI between the age groups may be due to a lack of occupational and leisure time physical activity, and sedentary lifestyle.

According to some studies, body composition may correlate with physical performance in police officers (Mitrovic et al.; Dawes et al., 2016; Kukic et al.; Pihlainen et al.). For instance, the above-normal PBF in law enforcement officers negatively affected the performance of push-ups, vertical jump, and the estimated VO2max in the 1.5-mile run test, when compared to officers with lower fat mass (Dawes et al., 2016). Comparing to Dawes et al. (2016) this study did not follow the physical performance of FPO, however, a gradual and significant increase in FM and FMI may be alarming. Moreover, the inverse gradual magnitude of between-age differences can be noticed in PBF and PSMM until the age of 35 years, after which the magnitude exponentially rises (Fig. 3), proving that at this age the negative effects of age are becoming very significant. These trends may accentuate the risk of reduced occupational performance, health status, and increased injury proneness.
The difference in BM and BMI between younger and older FPO in this study was based on FM, which may be an alarming signal for increased health risks and risk of injuries as well as for the lowered physical performance. These findings could help designing more precise physical fitness assessment method and adequate training program.

\section{ACKNOWLEDGEMENTS}

The paper is a part of the project III47015, funded by the Ministry of Education, Science and Technological Development of the Republic of Serbia - Scientific Projects $2011-2018$

KUKIC, F.; SCEKIC, A.; KOROPANOVSKI, N.; CVOROVIC, A.; DAWES, J. J. \& DOPSAJ, M. Diferencias de composición corporal relacionadas con la edad en los oficiales de la policía femenina. Int. J. Morphol., 37 (1):302-307, 2019.

RESUMEN: Debido a que el desempeño en los trabajos policiales puede depender de la composición corporal y las capacidades físicas, las mujeres tienen menos probabilidades de convertirse en agentes de policía. Sin embargo, existe escasa información sobre las diferencias relacionadas con la edad en la composición corporal entre las mujeres policías (MP). Por lo tanto, el objetivo de este estudio fue investigar la asociación entre la edad y la composición corporal en la MP. La composición corporal de 95 MP se evaluó y dividió en 4 grupos etarios: $21-25($ edad $=23.58 \pm 0.84$ años, altura corporal $[\mathrm{AC}]=1.61 \pm$ $0.04 \mathrm{~m}$, masa corporal $[\mathrm{MC}]=65,55 \pm 12,59 \mathrm{~kg}) ; 26-30(\mathrm{edad}=$ $28,24 \pm 1.20$ años, $\mathrm{AC}=1,61 \pm 0,04 \mathrm{~m}, \mathrm{MC}=72,08 \pm 12,80$ $\mathrm{kg}) ; 31-35(\mathrm{edad}=32,73 \pm 1,59$ años, $\mathrm{AC}=1,62 \pm 0,06 \mathrm{~m}, \mathrm{MC}$ $=74,88 \pm 12,22 \mathrm{~kg}) ;$ y $36-40($ edad $=37,71 \pm 1.40$ años, $\mathrm{AC}=$ $1,61 \pm 0,08 \mathrm{~cm}, \mathrm{MC}=77,38 \pm 11,61 \mathrm{~kg})$. Se midieron ocho características de la composición corporal utilizando la impedancia bioeléctrica (InBody 720): MC, índice de masa corporal (IMC), índice de masa grasa (IMC), masa grasa (MG), masa grasa del tronco (MGT), porcentaje de masa corporal grasa (PMC), masa muscular esquelética (MME) y porcentaje de masa muscular esquelética (PMME). Se utilizó un análisis de varianza multivariable (MANOVA) con la prueba post-hoc de Bonferroni ( $p<0.05)$ y el tamaño del efecto de Cohen (ES) para determinar diferencias significativas en las variables antropométricas por edad. Se observaron diferencias estadísticamente significativas en $\mathrm{MC}(\mathrm{G}=3,412, \mathrm{p}=0,021), \mathrm{IMC}(\mathrm{G}=3,662, \mathrm{p}=0,015), \mathrm{MG}$ $(\mathrm{G}=3,411, \mathrm{p}=0,021)$ y IMG $(\mathrm{G}=3,479, \mathrm{p}=0,019)$. Se produjo un ES inverso grande en la tendencia de las diferencias relacionadas con la edad en PGC y PMME. La MC es más alta en relación con la edad debido a la $\mathrm{MG}$, lo que puede causar una disminución en el PMME. El período más crítico parece ser entre 30-35 años.

PALABRAS CLAVE: Masa corporal; Grasa corporal; Músculo; Cambios corporales. 


\section{REFERENCES}

Aandstad, A.; Holtberget, K.; Hageberg, R.; Holme, I. \& Anderssen, S. A. Validity and reliability of bioelectrical impedance analysis and skinfold thickness in predicting body fat in military personnel. Mil. Med., $179(2): 208-17,2014$

Anderson, G. S. \& Plecas, D. B. Predicting shooting scores from physical performance data. Polic. Int. J. Police Strateg. Manag., 23(4):525537, 2000.

Anderson, G. S.; Plecas, D. \& Segger, T. Police officer physical ability testing - Re-validating a selection criterion. Polic. Int. J. Police Strateg. Manag., 24(1):8-31, 2001.

Birzer, M. L. \& Craig, D. E. Gender differences in police physical ability test performance. Am. J. Police, 15(2):93-108, 1996

Boyce, R. W.; Jones, G.; Lloyd, C. L. \& Boone, E. L. A longitudinal observation of police: Body composition changes over 12 years with gender and race comparisons. J. Exerc. Physiol. Online, 11(6):1-13, 2008.

Charles, L. E.; Burchfiel, C. M.; Violanti, J. M.; Fekedulegn, D.; Slaven, J. E.; Browne, R. W.; Hartley, T. A. \& Andrew, M. E. Adiposity measures and oxidative stress among police officers. Obesity (Silver Spring), 16(11):2489-97, 2008

Christie, B. Doctors revise declaration of Helsinki. BMJ, 321(7266):913, 2000

Dawes, J. J.; Orr, R. M.; Elder, C. L. \& Rockwell, C. Association between body fatness and measures of muscular endurance among part-time swat officers. J. Aust. Strength Cond., 22(4):33-7, 2014.

Dawes, J. J.; Orr, R. M.; Flores, R. R.; Lockie, R. G.; Kornhauser, C. \& Holmes, R. A physical fitness profile of state highway patrol officers by gender and age. Ann. Occup. Environ. Med., 29:16, 2017.

Dawes, J. J.; Orr, R. M.; Siekaniec, C. L.; Vanderwoude, A. A. \& Pope, R. Associations between anthropometric characteristics and physical performance in male law enforcement officers: a retrospective cohort study. Ann. Occup. Environ. Med., 28:26, 2016.

Dimitrijevic, R.; Umicevic, D. \& Dopsaj, M. Morphological model of female members of the Communal Police of Belgrade. Glasnik Antropoloskog drustva Srbije, (48):97-106, 2013.

Dopsaj, M.; Markovic, M.; Kasum, G.; Jovanovic, S.; Koropanovski, N.; Vukovic, M. \& Mudric, M. Discrimination of different body structure indexes of elite athletes in combat sports measured by multi frequency bioimpedance method. Int. J. Morphol., 35(1):199-207, 2017.

Hauschild, V. D.; DeGroot, D. W.; Hall, S. M.; Grier, T. L.; Deaver, K. D.; Hauret, K. G. \& Jones, B. H. Fitness tests and occupational tasks of military interest: a systematic review of correlations. Occup. Environ. Med., 74(2):144-53, 2017.

Kelly, K. R. \& Jameson, J. T. Preparing for combat readiness for the fight: physical performance profile of female U.S. marines. J. Strength Cond. Res., 30(3):595-604, 2016.

Kirlin, L. K.; Nichols, J. F.; Rusk, K.; Parker, R. A. \& Rauh, M. J. The effect of age on fitness among female firefighters. Occup. Med. (Lond.), 67(7):528-33, 2017.

Kukic, F. \& Dopsaj, M. M. Factorial analysis of body composition in Abu Dhabi policemen. Bezbednost, 59(2):5-26, 2017.

Kukic, F.; Dopsaj, M.; Dawes, J.; Orr, R. \& Cvorovic, A. Use of human body morphology as an indication of physical fitness: implications for police officers. Int. J. Morphol., 36(4):1407-12, 2018.

Mitrovic, B.; Djordjevic, A.; Dopsaj, M. \& Vuckovic, G. Relations between Morphological Dimensions and Aerobic Capacity of Special Forces Members at Ministry of Interior of the Republic of Serbia. Nis, 18th Scientific Conference, FIS Communications 2015 in Physical Education, Sport and Recreation. Faculty of Sport and Physical Education, University of Nis, 2015. pp.299-304.

Orr, R.; Pope, R.; Stierli, M. \& Hinton, B. Grip strength and its relationship to police recruit task performance and injury risk: a retrospective cohort study. Int. J. Environ. Res. Public Health, 14(8):E941, 2017.
Pihlainen, K.; Santtila, M.; Häkkinen, K. \& Kyröläinen, H. Associations of physical fitness and body composition characteristics with simulated military task performance. J. Strength Cond. Res., 32(4):1089-98, 2018.

Sörensen, L.; Smolander, J.; Louhevaara, V.; Korhonen, O. \& Oja, P. Physical activity, fitness and body composition of Finnish police officers: a 15-year follow-up study. Occup. Med. (Lond.), 50(1):3-10, 2000.

Stevens, J.; Cai, J.; Pamuk, E. R.; Williamson, D. F.; Thun, M. J. \& Wood, J. L. The effect of age on the association between body-mass index and mortality. N. Engl. J. Med., 338(1):1-7, 1998.

Sullivan, G. M. \& Feinn, R. Using effect size-or why the p value is not enough. J. Grad. Med. Educ., 4(3):279-82, 2012.

Wells, J. C. Sexual dimorphism of body composition. Best Pract. Res. Clin. Endocrinol. Metab., 21(3):415-30, 2007

Corresponding author:

Filip Kukic

Police Sports Education Center

Airport Road

Rawdhat Area

The Porsche Building, Apartment 1205

P.O. Box 253

Abu Dhabi

UNITED ARABA EMIRATES

Email: filip.kukic@gmail.com

Received: 29-08-2018

Accepted: 16-10-2018 